\title{
Drivers of E-Marketing Adoption among Small and Medium Enterprises (SMEs) and Variations with Age of Business Owners
}

\author{
Nobukhosi Dlodlo \\ Lecturer, Department of Marketing and Sport Management \\ Faculty of Management Sciences, Vaal University of Technology \\ Private Bag X021, Vanderbijlpark, 1900 \\ Email: nobukhosid@vut.ac.za \\ Professor Manillal Dhurup \\ Executive Dean, Faculty of Management Sciences \\ Vaal University of Technology, Private Bag X021, Vanderbijpark, 1900 \\ Email: royd@vut.ac.za
}

\section{Doi:10.5901/mjss.2013.v4n14p53}

Abstract

In a knowledge society, organisations need to develop competitive advantages through the effective utilization of electronic marketing in order to succeed in markets. The study complements existing literature and research by examining factors that assist in the adoption of electronic marketing by SMEs. Primary data was collected using a quantitative research technique through the use of a structured questionnaire. A random sample of 123 SMEs were drawn randomly within the various municipal areas in the Vaal Triangle. Principal component analysis with Varimax rotation was employed to identify the factors pertaining to the drivers of e-marketing adoption among SMEs. A five-dimensional structure, pertinent to the understanding of SMEs decisions to adopt e-marketing technology was established. Perceived ease of use (PEOU), external pressure, mission, job performance, resource availability and compatibility were found to be significant drivers of e-marketing adoption. The analysis present marketers with strategies to amplify Internet technological adoption. It further provides insight for SME owners that may potentially influence the implementation of intervention strategies that support e-marketing adoption. A study on the potential influence of e-marketing on firm performance in emerging economies is a worthy area for future research.

Keywords: E-marketing, SMEs, drivers, adoption, factor analysis, ease of use.

\section{Introduction}

With the advent of technology the Internet has come a long way within a very short time as a mainstream business tool that has transformed business activities (Rashid \& Al-Qirim, 2001). The metaphor of "a tidal wave that washes over all industries and drowns all those who don't learn to swim in it" has been used repeatedly by marketing practitioners to describe usage of the Internet as a marketing channel; giving the more reason for Small and Medium Enterprises (SMEs) to adopt its usage as a marketing avenue (Gay, Charlesworth \& Esen, 2007).

According to Vuuren and Groenewald (2007) the creation of the SME sector plays an important role towards contributing to the economic growth of an economy and averting the low gross national product, high unemployment and levels of poverty in countries. In line with the August report from the Parliamentary Monitoring Group (Republic of South Africa, 2009), economies can benefit from the build-up of efficient SMEs which is in sync with government's plans to create about half a million jobs for South Africans by the end of the year, 2009. In this regard, adoption of Internet marketing strategies has the potential to contribute to the exponential growth of the SME sector. However, despite its potential as a marketing tool, actual use of e-marketing has not met with expectations (Elliot \& Boshoff, 2007).

Electronic marketing (henceforth referred to as e-marketing) is one of the rapidly growing forms of digital marketing in may developed economies. The E-Marketing Association defines e-marketing as "the use of electronic data and applications for planning and executing the conception, distribution, promotion and pricing of ideas, goods and services to create exchanges that satisfy individual and organisational objectives" (Burgess \& Bothma, 2007:19). With regard to larger multi-national organisations, often business operations are internationalised; with pre-order and post-order processing occurring over the Internet platform in order to expedite transaction processing (Awa, Nwibere \& Inyang, 
2010). In addition, customer relationships are built and maintained through online activities that facilitate the exchange of ideas, products and services in order to satisfy the marketing goals of both parties (Gay et al., 2007).

Porter (2001) highlights that marketers are able to identify and satisfy customer needs and preferences through monitoring website visitations, e-mails, online surveys and chat rooms conducted on the Internet. Awa et al. (2010) opines that e-marketing presents a virtual marketplace within which firms buy, sell, distribute and provide sales support for their products and services. Zhao (2005) further posits that business enterprises can also develop custom-made products and services that meet the precise needs of consumers. This in turn, culminates in high returns for businesses. The adoption of e-marketing also enables businesses to promote their products and services to the public through advertisements, banner advertisements, e-mails and mobile phone competitions (Chaffey \& Smith, 2005). Furthermore, businesses are also better able to effectively serve global markets and distribute goods and services to customers through e-marketing adoption (Harris \& Dennis, 2002).

Some authors (Mutula \& van Brakel, 2006; Chaston, 2000) postulate that Internet marketing adoption varies widely among SMEs as the technologies facilitate the enhancement of competitive advantages. In addition, similar opportunities for enterprises to develop their systems are offered through Internet Marketing. This study reviews the relevant literature relating to the importance of the SME sector, e-marketing and the drivers of e-marketing adoption.

\subsection{The SME sector and its importance}

There is no universally acknowledged definition of SMEs as the definitions differ across industry sectors and countries (Awa et al., 2010). Varied criteria have been employed by authors in an effort to delimit this sector with number of employees, gross assets, sales turnover and investment level turning out as the most prevalent criterion (Gibson \& van der Vaart, 2008:4). The South African government's general definition for SME is any business with fewer than 200 employees; where fewer than fifty workers are deemed small and between 50 and 200 medium sized. In addition the SME has an annual turnover of R5 million and the SME owners are involved directly in the daily management issues (National Small Business Act 1996 amended 2004). According to the Department of Trade and Industry (DTI, 2005) a small business is owner managed; registered with local authorities and conducts business activities from fixed premises. In the current study, the delimitation for medium enterprises shall comprise enterprises that generate between R8 million and R16 million in gross annual turnover and further constitute between 100 and 200 formal employees (Cronje, Du Toit \& Motlatla, 2004). Similarly, small enterprises are perceived as those enterprises that earn an average of below R8 million annual turnover and also formally employ between five and 100 persons on a full time basis.

Falkena (2000) points to the fact that SMEs are characterised by a decentralisation of power to a new management layer (between the SME operator and employees). Thus, SMEs have vast potential of growing into large businesses, should they receive sufficient capital injections. Current estimates indicate that the Gross Domestic Product (GDP) distribution amongst the South African SME sector is 51 percent by medium enterprises and 13 percent by small businesses (Tassiopoulos, 2010). In global economies, SME GDP distribution is over 80 percent (Jutla, Bodorick \& Dhaliwal, 2002), as compared to the 65 percent contribution from their larger counterparts (Cronje et al., 2004). This sector tends to differ from large enterprises in that they stimulate competition, bring about a diversity of products and services, have increased flexibility in their internal and external systems and possess hands-on managerial style, which facilitates faster decision-making (Kendall et al., 2001). Adoption of e-marketing strategies can go a long way in representing the small business sector in the national economy in order stay ahead and maintain a competitive advantage (Steyn \& Leonard, 2012). However, in South Africa alone, SMEs contribute 37 percent to employment (Soontiens, 2002; Barry \& Milner, 2002). They also provide a variety of goods and services for customers to choose from, some of which might otherwise not be provided for by large businesses (Jackson, 2004). These business entities act as a catalyst for economic growth as well as the development of the arts, human resources, manufacturing and sport sectors (Cronje et al., 2004). Moodley (2002) also reported that SMEs in South Africa are important because of their potential for job creation and distribution of wealth, resulting in a multiplier effect on the socio-economic activities of a country. They are breeding incubators for entrepreneurial talent and a testing ground for new products (Chaston, 2000). In this regard SMEs are agents of change, widely facilitating innovation and competition within various national economies (Barry \& Milner, 2002).

\subsection{Drivers of e-marketing adoption}

In knowledge economies, high competition among profit-making businesses is of paramount importance in order to 
attract customers. There is also a need to keep pace with contemporary business requirements in ensuring that marketing's standing as a business discipline is a principle that is closely upheld by all enterprises. Saffu, Walker and Hinson (2008) identify the increased use of the Internet for conducting business as one of the most significant trends in the past decade. This backdrop necessitates that SMEs should integrate Internet-driven marketing principles such as emarketing into their mainstream business practices. The drivers of e-marketing adoption are discussed broadly below.

Internet marketing adoption depends on its perceived usefulness (PU) which implies the user's assessment of the ability of specific information technology to increase his or her performance at some task or activity (Pearson \& Grandon, 2004; Parker \& Castleman, 2009). PU is the degree to which a person believes that using a particular system would be better than alternative systems in enhancing his or her job performance (Davies, Bargozzi \& Warshaw, 1989). Lim (2010) contends that the perceived marketing benefits of Internet technologies are pertinent towards the decisions by SMEs to accept and implement e-marketing for their business transactions. Internet marketing adoption is also influenced by perceived ease of use (PEOU) which measures the extent to which an organisation believes that investment in electronic marketing requires minimum effort (Davies et al., 1989). The complexity of the user interface reduces system evaluation and lessens the intention to adopt specific Internet technologies (Opia, 2008). Venkatesh (2000) asserts that PEOU has direct and positive impact on perceived usefulness of e-marketing technology since improvements in technology ease of use assist in bringing about positive performance and ultimately define PU. Moreover, Awa et al. (2010) underscore that PU and PEOU will have significant effects on the adoption of Internet technology by SMEs. Rogers (1995) defines technology compatibility as the degree to which the Internet is consistent with the experience, values and needs of the adopter. Organisations will adopt technologies that are attuned to their line of business but such technologies have to offer relative advantages (Rashid \& Al-Qirim, 2001). Avid early Internet technology adopters have been noted particularly in the business consultancy services and higher educational institutions (Awa et al., 2010), retail sector, financial services, airliners and hotels (Fillis, Johannson \& Wagner, 2004). Moreover, firms with a greater reliance on media such as television, catalogues, billboards and mobile phones are more likely to adopt and use the Internet for marketing purposes as they already possess a higher level of technology compatibility (Khan, 2007). A noteworthy determinant of technology adoption is the owner-manager's knowledge about Internet marketing. Knowledge could be sourced from the SME operator's network of personal contacts (Elliot \& Boshoff, 2007; Poon \& Swatman, 1997). Ultimately the spill over of information from users to non-users can positively contribute to the adoption of Internet technologies (Hollenstein, 2004).

According to Triandis (2004:90) "...there is no psychological or technological acceptance process that is not shaped to some extent by culture". National culture and organisational culture are a driving force behind the acceptance and implementation levels of electronic marketing among SMEs (Saffu et al., 2008; Modimogale \& Kroeze, 2011). National culture provides the appropriate setting and social embeddedness of the technological change processes. Opportunely, positive outcomes have been reported within the South African context with increased government support mainly through the development of Information Communication Technology (ICT) Infrastructure and the deregulation of the telecommunications sector (Statistics South Africa 2009). This has made Internet services affordable to many users (Kyobe, 2011). In addition, the South African Government has proactively set up organisations through the Information Communication Technology (ICT) Sectoral Education and Training Agency (SETA) as well as the Information Systems, Electronics and Telecommunications Technologies (ISETT) SETA to try and increase ICT skills base. In addition, the country has witnessed the extensive development of cyber-infrastructure and mobile technologies (Abrahams \& Goldstuck, 2010). Findings of Dlodlo, Nleya and Adigun (2006) further intimate that the relative absence of supporting infrastructure for wired services is a contributing factor that has ultimately increased the demand for wireless applications.

The adoption of e-marketing is also driven by industry type (Poon \& Swatman, 1999). In this regard, the public, education and charity organisations have been identified as being the lowest adopters of Internet technology (Maguire, Koh \& Magrys, 2007). A study conducted by Sparkes and Thomas (2001) also revealed that global adoption of emarketing by SMEs has been the slowest in the agricultural sector. These findings contradict earlier research findings of Teo and Tan (1998) who found that no significant relationship exists between industry sector and adoption of emarketing.

SMEs specialising in manufacturing products are less likely to adopt Internet technologies as compared with knowledge intensive service organisations such as consultancies (Martin \& Matlay, 2001; Sadowski, Maitland \& Dongen, 2001). Esteves (2009) attribute this trajectory to the fact that a majority of manufacturing SMEs are still in the lower stages of adoption as these firms perceive very low levels of supply chain benefits from e-business. However, Chan and Swatman (2000) found that technology intensive industries have reaped the rewards of Internet technology which are yet to be experienced by traditional marketers. These findings are at variance with Matlay and Addis' (2003) suggestion that 
there is no association between Internet adoption and technological content of a business environment.

In order to adopt electronic marketing appropriately and also benefit from its usage, SMEs need to be internally and externally ready (Mutula \& van Brakel, 2006). This state of preparedness is termed 'e-readiness of an SME' and may be defined as the ability of a company to successfully adopt, use, and benefit from e-marketing (Fathian, Akhavan \& Hoorali, 2008). Internal readiness can be defined in the context of availability of human staff skills (Stansfield \& Grant, 2003; Kohn \& Husig, 2006), financial and technological resources (Lee \& Cheung, 2004), top management's enthusiasm to champion the Internet marketing technology adoption process (Teo \& Tan, 1998; Levy \& Powell, 2002), compatibility of the firm's culture and values with the technology adoption process (Bruque \& Moyano, 2007; Saffu et al., 2008).

It is suggested that after the initial e-marketing adoption phase, external readiness plays an essential role upon the business fully realising the benefits of the technology. The preparedness of customers and business partners to allow an electronic conduct of marketing activities significantly influences the institutionalisation of the Internet marketing concept among SMEs (Ghobakhloo, Arias-aranda \& Benitez-amado, 2011). National readiness for Internet marketing adoption and implementation for commercial business also remains a priceless driver. South Africa is currently at 2.78, as measured on a five-point Likert scale (Uzoka, Shemi \& Seleka, 2007), which is greater than the mean of 2.22 for the African continent with scale ranges from one denoting a state of non-readiness, to five which reflects a state of high readiness. Therefore, a score of 2.78 is considered to be a moderate or fair degree of e-readiness.

\section{Problem Statement}

The Internet is the fastest growing technology in the world, taking approximately seven years to reach a $25 \%$ market share from its conception, as opposed to the telephone that took 35 years, and the television which took 26 years (Singh, 2002). Despite the growing consciousness and enthusiasm for electronic marketing, only a few SMEs are exploiting its substantial benefits (Awa et al., 2010). Moreover, there is scant evidence of long-term strategic development of emarketing technologies within SMEs that are already employing the systems especially among less developed countries (Fillis et al., 2004). In Nigeria, Internet commerce diffusion is rather slow but steady (Awa et al., 2010); underdeveloped in Botswana (Mutula 2002; Uzoka et al., 2007); showing growth potential in Egypt and Morocco (MiniWatts Marketing Group, 2011) and generally still needing proper stimulation and re-evaluation among African countries.

In a study undertaken by Zaayman (2003), however, only 17 percent of the SMEs in South Africa believe that electronic business transactions are critical to their operations. From current users, considerable variations still exist in their adoption of e-marketing. Some owners of very small businesses may adopt e-marketing as a means of defending their autonomy in business and thus adopt the technologies in a casual and ad hoc manner (Gilmore, Gallagher \& Henry, 2007). This is the current scenario despite ample evidence to suggest that e-marketing can facilitate improved business practices particularly within the SME fraternity (Modimogale \& Kroeze, 2011; Mora-Monge, Azadegan and Gonzalez 2010; Whiteley, 2000).

The advent of Internet marketing offers SMEs a new frontier of opportunities and challenges. An understanding of the drivers that influence the adoption of e-marketing can allow small and medium firms to create solutions and plans to attract consumers to their products and services, thus enabling them to gain a greater representation in the global industry market (Ghobakhloo et al., 2011). In South Africa, little is known and understood about the acceptance and implementation of e-marketing. This is because e-marketing adoption among SMEs is still in its infancy stages and its acceptance and use by firms is still limited (Saffu et al., 2008).

To date, limited research has been conducted on the drivers of e-marketing adoption. Currently, there is no international database that provides information on the use of ICTs in small and medium enterprises in developing countries (United Nations, 2004). This study contributes to our understanding of the reasons behind e-marketing drivers among SMEs in an African country context.

\section{Purpose of the Study}

The purpose of this study is to establish the drivers of e-marketing adoption by SMEs in South Africa. The study follows the adoption research conventions such as those promulgated in the studies of Fillis et al. (2004); Uzoka et al. (2007) and Modimogale and Kroeze (2011) which intended to provide explanations as to why particular adoption behaviour may be observed at organisational level. 


\section{Research Design and Methodology}

Primary data was collected using a quantitative research technique with the use of a structured questionnaire.The rationale for selecting a quantitative study was that it is cost effective and easier to administer compared to a qualitative approach (Malhotra, 2010). In addition, quantitative studies possess the rigor and coherence that is necessary for addressing the dimensions and internal consistency that underpin the adoption of e-marketing by SMEs.

\subsection{Population and the sample}

The target population was restricted to Managers, SME owners, IT specialists and Heads of Marketing Departments within SMEs operating in the Vaal Triangle region of South Africa. According to Companies and Intellectual Property Registering Office (CIPRO) there are 36000 SMEs in Gauteng province. More precisely, possible enterprises were identified from three databases namely; the Gauteng Enterprise Propeller (GEP), the Vaal Triangle business directory as well as 3 Vaal district municipality records as these sources provides more specific SME data on the Southern Gauteng region. A list of possible enterprises was drawn and common names were removed until a random sample of 515 SME organisations was established and contacted to participate in the survey. Only 168 organisations voluntarily agreed to provide information for the study and therefore, were allowed to participate in the survey. Some enterprises were not willing to voluntarily co-operate were excluded from the study. Twenty questionnaires were incomplete questionnaires and were discarded. A total of 123 complete questionnaires were finally used for analysis.

\subsection{Instrumentation and data collection}

In order to achieve the objectives of the current study, a comprehensive literature review was conducted on the underlying determinants of Internet marketing adoption among businesses. This theoretical review culminated into the design of a self-administered questionnaire based on the adapted technology adoption scales used by Davies et al. (1989) and Chau (1996). These scales were further validated within the context of e-business adoption among firms in the studies of Pearson and Grandon (2004); Beheshti and Sangari (2007) and Parker and Castleman (2009). The questionnaire was divided into three sections, namely; $A, B$, and $C$. Section A of the questionnaire primarily obtained demographic information from the respondents. Section B of the questionnaire solicited information on the profile specific attributes of the responding businesses. Section $\mathrm{C}$ requested information on the drivers of Internet marketing adoption by SMEs. The items in section $\mathrm{C}$ were scored on a 7-point Likert scale which ranged from 1 (strongly disagree) to 7 (strongly agree). An accompanying cover letter was attached to the questionnaire to highlight the purpose of the study. Pre-testing was conducted with a convenient sample of five academics in marketing and IT fields in order to ensure that the questionnaire met expectations in providing accurate information, usage of appropriate wording, questioning sequence and to assess the extent to which respondents understood the questions clearly. The pretest also served to determine the anticipated questionnaire completion time. Based on feedback from the pretest, minor revisions were made to the questionnaire and a pilot study was conducted with 20 SMEs (10 small and 10 medium enterprises). This technique was used as an indispensable aid for developing the final questionnaire.

The principal researcher selected and trained three fieldworkers who assisted in the administration of questionnaires. These students were screened and selected from a Marketing Research 4 class from a university. They were trained on various aspects of questionnaire fieldwork administration.

During the questionnaire administration phase, various ethical considerations such as the participants' right to anonymity, confidentiality, privacy or non-participation and informed consent were adhered to.

\section{Results}

The results are described taking into account the composition of the sample in terms of small and medium enterprises followed by a descriptive analysis of the variables relating to the drivers of e-marketing adoption. Thereafter, the factor analytical procedure and extraction of factors is described. , 
Table 1: Descriptive statistics, communalities and construct reliability

\begin{tabular}{|l|c|c|c|}
\hline \multicolumn{1}{|c|}{ Construct } & Mean & Standard Deviation & Communalities \\
\hline Perceived ease of use (PEOU) & & & \\
Ease of use & 3.50 & 1.544 & .685 \\
Flexibility of use & 4.13 & 1.498 & .894 \\
Understandability & 4.28 & 1.450 & .777 \\
Top management is very enthusiastic & 4.56 & 1.174 & .552 \\
\hline External Pressure and mission & & & \\
Competitors' are pressuring us & 5.55 & .985 & .781 \\
The industry sector is pressuring us & 5.67 & .864 & .593 \\
E-marketing is consistent with our organisation's goals & 5.69 & .888 & .661 \\
E-marketing is consistent with our organisation's values & 5.40 & 1.092 & .758 \\
\hline Job performance & & & \\
Improved job performance & 5.85 & .947 & .778 \\
Improved productivity & 5.68 & .986 & .816 \\
Improved job effectiveness & 5.53 & .908 & .690 \\
\hline Resource availability & & & \\
Technological resources to adopt e-marketing & 3.48 & 1.133 & .860 \\
Adequate staff skills to adopt e-marketing & 3.38 & 1.177 & .807 \\
\hline Compatibility & & & .795 \\
E-marketing is consistent with our organisation's culture & 4.54 & 1.339 & .758 \\
E-marketing is consistent with our organisation's & 3.89 & 1.307 & \\
technology infrastructure & & & \\
\hline
\end{tabular}

Table 1 depicts the mean scores of the drivers of e-marketing adoption which reflect on the location of responses on a seven-point Likert scale. The dispersion of the scores revealed high means ranging between 5.40 and 5.85 on the external pressure and performance dimensions. This indicates that the respondents were in agreement that these dimensions as measured by external pressure to adopt from competitors among other stakeholders and the desire to enhance the performance and productivity of employees on the job; had very high influence upon the SME owners/managers decisions to adopt e-marketing. The two dimensions, namely perceived ease of use and compatibility revealed mean scores ranging between 3.50 and 4.56 indicating that moderate to high propensity to adopt e-marketing is propelled by the degree to which SME owners/managers consider the e-marketing tools as being easy to adapt to and also consistent with company values, culture and requirements of management (Harrison \& Waite, 2006). Surprisingly, there was low to moderate agreement with regard to the availability of financial and technological skills and resources as a driver in the adoption of e-marketing tools; as depicted by mean scores ranging between 3.38 and 3.48 on this dimension. The standard deviations ranged between 0.864 and 1.544 . Communalities were high ranging between 0.552 and 0.894 which indicated high levels of association among the scale items thus 'acceptable fit' with the constructs.

\subsection{The sample composition}

115 businesses (93\%) were classified within the small sector and only 8 firms (7\%) qualified for classification as medium enterprises based on number of employees and annual turnover (See Table 2).

Table 2: Sample composition

\begin{tabular}{|c|l|c|c|c|}
\hline Enterprise size & $\begin{array}{c}\text { Number of employees } \\
\text { (employed full-time) }\end{array}$ & Annual turnover (Rands) & Count (n) & $\%$ \\
\hline Small & Between 5 and100 & Less than 8 Million & 115 & 93 \\
\hline Medium & Greater than 100 but less than 200 & Between8 Million and 16 Million & 8 & 7 \\
\hline \multicolumn{2}{|c|}{ TOTAL } & 123 & 100 \\
\hline
\end{tabular}

Of the 123 businesses that were included in the survey, 77 respondents (63\%) were males and 46 respondents were females (37\%). The largest category of respondents was between 40 to 49 years which comprised 39 percent of the sample $(n=48)$. This was followed by the 30 to 39 years age group which was represented by $34 \%$ of the sample $(n=42)$. Furthermore, 15 percent of the respondents were under 30 years of age $(n=18)$, whereas 12 percent of the sample 
$(n=15)$ were 50 years and older. Seven out of ten standard industry classification (SIC) sectors were represented in the sample.

The industry representation of the sample is reported in Figure 1 with a majority of responding businesses clustered the community, social and personal services which constituted 32 respondents (26\%). This sector comprises mostly hairdressing, medical care as well as recreational services. The wholesale, retail, clothing, hotel and restaurant business sector comprised 21 respondents (17\%) followed by the manufacturing and financial services sectors each constituting 18 respondents (15\%). The transport, storage and communication sector comprised 14 respondents (11\%) of the sample.

Figure 1: Industry representation of sample

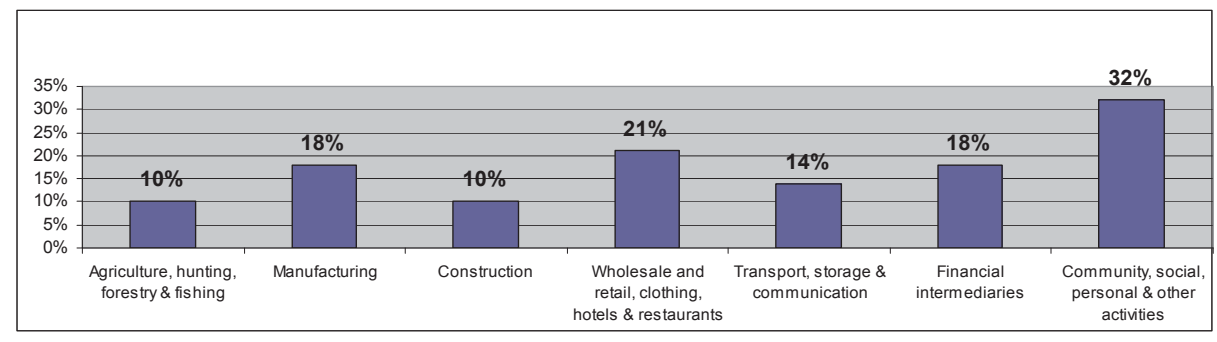

\subsection{Factor analysis of e-marketing adoption drivers}

The main emphasis of this procedure was to establish the drivers that are pertinent in encouraging SMEs to adopt emarketing. A principal components factor analysis with Kaiser Normalisation was conducted on the twenty-item scale to develop a set of factors that can be classified as drivers of Internet marketing adoption among SMEs.

The appropriateness of factorability on the data set was formally determined using the Kaiser-Meyer-Olkin (KMO) test as well as Bartlett's test of Sphericity. The approximate chi-square was 941.123 with 105 degrees of freedom, significant at $p<0.0000$. The KMO value was 0.619 rendered the data suitable for factor analysis (Malhotra, 2010).

The percentage of variance analysis, scree plot and the eigenvalue criterion $(>1)$ provided primary evidence that five factors could best explain the drivers of e-marketing adoption. The total variance explained by the factors was $74.7 \%$ which according to Malhotra (2010) is satisfactory.

Exploratory factor analysis was performed with Varimax rotation in order to examine low factor loadings, multiple factor loadings and unstable item-total correlations (Malhotra, 2010). The rotated item reduction procedure revealed a clearer factor structure with loadings ranging from 0.601 to 0.933 . This is consistent with the guidelines of Uzoka et al. (2007) and Hair et al. (1992) who maintain that loadings of $\pm 0.30=$ minimum levels; $\pm 0.40=$ important levels and \pm 0.50 and greater are considered more important. The total percentage of variance, eigen value criterion $(>1)$, scree plot and interpretability of factors resulted in a five factor structure with fifteen variables. The final factors structure and the psychometric properties of the scale are reported in Table 3.

Table 3: Rotated factor-loading matrix: e-marketing adoption drivers and psychometric properties of the scale

\begin{tabular}{|l|c|c|c|c|c|c|}
\hline \multicolumn{1}{|c|}{ Scale Item } & $\begin{array}{c}\text { Factor 1 } \\
\text { Perceived Ease } \\
\text { Of Use }\end{array}$ & $\begin{array}{c}\text { Factor 2 } \\
\text { External Pressure } \\
\text { And Mission }\end{array}$ & $\begin{array}{c}\text { Factor 3 } \\
\text { Job } \\
\text { Performance }\end{array}$ & $\begin{array}{c}\text { Factor 4 } \\
\text { Resource } \\
\text { Availability }\end{array}$ & $\begin{array}{c}\text { Factor 5 } \\
\text { Compatibility }\end{array}$ & $\begin{array}{c}\text { Item-Total } \\
\text { Correlation }\end{array}$ \\
\hline $\begin{array}{l}\text { Technological resources to adopt e- } \\
\text { marketing }\end{array}$ & .118 & .089 & .005 & .915 & .104 & .722 \\
\hline $\begin{array}{l}\text { Adequate staff skills to adopt e- } \\
\text { marketing }\end{array}$ & .081 & .016 & .040 & .874 & .184 & .722 \\
\hline Ease of use & .785 & .099 & .013 & .035 & .241 & .663 \\
\hline Flexibility of use & .933 & .043 & .123 & .108 & .287 & .848 \\
\hline Understandability & .867 & .048 & .081 & .021 & .128 & .712 \\
\hline Competitors' are pressuring us & .011 & .873 & .069 & .047 & .109 & .633 \\
\hline The industry sector is pressuring us & .339 & .601 & .223 & .239 & .102 & .399 \\
\hline
\end{tabular}




\begin{tabular}{|c|c|c|c|c|c|c|}
\hline $\begin{array}{l}\text { Top management is very } \\
\text { enthusiastic }\end{array}$ & .670 & .066 & .002 & .267 & .166 & .547 \\
\hline $\begin{array}{l}\text { E-marketing is consistent with our } \\
\text { organisation's goals }\end{array}$ & .265 & .707 & .057 & .141 & .259 & .631 \\
\hline $\begin{array}{l}\text { E-marketing is consistent with our } \\
\text { organisation's values }\end{array}$ & .114 & .737 & .028 & .245 & .377 & .566 \\
\hline $\begin{array}{l}\text { E-marketing is consistent with our } \\
\text { organisation's culture }\end{array}$ & .073 & .420 & .008 & .022 & .783 & .532 \\
\hline $\begin{array}{l}\text { E-marketing is consistent with our } \\
\text { organisation's technology } \\
\text { infrastructure }\end{array}$ & .198 & -.109 & .145 & .209 & .801 & .532 \\
\hline Improved job performance & .085 & .156 & .839 & .189 & -.077 & .593 \\
\hline Increased productivity & .116 & -.105 & .875 & .065 & .145 & .691 \\
\hline Increased job effectiveness & -.147 & .231 & .753 & .197 & .099 & .592 \\
\hline Eigen values & 3.47 & 2.83 & 2.12 & 1.58 & 1.18 & \multirow{4}{*}{$\begin{array}{l}\text { Overall } \\
\text { Cronbach a } \\
0.789\end{array}$} \\
\hline Percentage of variance & 23.16 & 18.91 & 14.13 & 10.55 & 7.91 & \\
\hline Cumulative percentage of variance & 23.16 & 42.08 & 56.21 & 66.77 & 74.69 & \\
\hline $\begin{array}{l}\text { Reliability of each factor (Cronbach } \\
\text { alpha value) }\end{array}$ & 0.850 & 0.755 & 0.785 & 0.838 & 0.694 & \\
\hline
\end{tabular}

Extraction Method: Principal Component Analysis. Rotation Method: Varimax with Kaiser Normalization. Loadings of 0.50 and more were considered significant.

\section{Discussion}

Factor one comprised four variables and was labelled perceived ease of use (PEOU). It accounted for 23.2 percent of the variance with an eigen value of 3.47. This factor combines the readiness of the firm in terms of top management enthusiasm or attitude towards change (Rogers, 1995) with Internet technology acceptance. It assumes that SME operators are willing to utilise e-marketing technologies if they are easy to use, flexible to implement and easy to understand. This notion is supported by empirical findings of Chau (1996); Clarke (2000) and Venkatesh (2000) who indicated that PEOU is a proven key determinant of users' intention to accept IT. Studies of Qingfei, Shaobo and Gang (2008:258) indicate that behavioural intention is a function of attitude and perceived ease of use. According to the Technology Acceptance Model (TAM) by Davies et al. (1989) PEOU measures the extent to which an organization believes that using a particular technology attracts mental effortlessness (Awa et al., 2010). Thus, PEOU emphasises Internet technology characteristics as being positively correlated with Internet marketing technology adoption (Harrison \& Waite, 2006).

The second factor accounted for 18.9 percent of the variance and reflected an eigen value of 2.83. This factor was labelled external pressure and mission. Factor 2 had four items loading onto it and these variables relates to the demands placed by suppliers, competitors and government which has an influence on an organisation's decision to adopt e-marketing. Mehrtens, Cragg and Miller (2001) affirm that before SMEs commence with the marketing their products and services online, they must be aware that their primary stakeholders, including suppliers, and key industry players are also supportive of the move. Moreover, influence of key players in the SMEs external technological environment such as government, competitors as well as a firm's trading partners gives SMEs sufficient impetus to get involved in Internet marketing practises (Bruque \& Moyano, 2007; Awa et al., 2010). In addition, this factor emphasises the view that a firm's strategy plays a pivotal role in e-marketing adoption (Bakos \& Treacy, 1986). The mission of an organisation; as defined by definitive statements about the firm's philosophy, character, identity, direction, goals and business strategy, significantly determine the possibility of adopting e-marketing (Martin, 2005; Federici, 2009).

Factor three was labelled job performance and it constitutes 14.1 percent of the variance and the eigen value for the factor was 2.12. This factor incorporates the extent to which the adoption of e-marketing technology can be expected to yield results regarding the productivity and effectiveness of employees. Reimenschneider, Harrison and Mykytyn (2003) established that SMEs make decisions to adopt Internet technologies based on the positive and negative consequences that could potentially result in the manner in which business is conducted. Chaston and Mangles (2003) validate these findings by asserting that the performance of managers is enhanced as their efforts are directed towards sustaining profitable customer relationships using electronic marketing strategies. Findings by Quayle (2002) also 
suggest that employee interest and productivity is a significant driver of e-marketing adoption by SMEs.

Factor four, labelled resource availability accounted for 10.6 percent of the total variance with an eigen value of 1.58. It constitutes of two item loadings that describe the availability of staff skills and technology infrastructure that may drive the adoption of e-marketing technologies within SMEs. These findings are in keeping with Mehrtens et al. (2001) and Shiau, Hsu and Wang (2009) who emphasised that financial resources, time and commitment of staff members are essential elements for facilitating an enabling environment for SMEs to adopt e-marketing strategies. Furthermore, Stansfield and Grant (2003) and Ramsey and McCole (2005) assert that organisational readiness to adopt e-marketing technology is made possible by the availability of financial, time and human (skilled personnel) resources. This can be inferred to mean that supportive conditions should be created through availing sufficient resources in order for electronic marketing and such related innovations, to triumph (Awa et al., 2010).

Factor five was labelled compatibility and this factor accounted for 7.9 percent of the total variance with an eigen value of 1.18. The items loading onto this factor relate to the organisational culture and the organisation's technology infrastructure to handle e-marketing strategies. These findings are congruent with studies of Bruque and Moyano (2007) who asserts that culture and its dynamics of flexibility, communication, measure of risk taking and attitude towards technology; are all important determinants of e-marketing adoption among SMEs. In this regard, SME environments with flexible and protagonist technology champions are a favourable driver of e-marketing adoption.

One way analysis of variance (ANOVA) was computed to establish whether there were any significant differences in terms of the variability between the identified factors and the age groups of the SME owners/managers. Respondents were divided into four age groups (Group 1= under 30 years; group 2=30-39 years; group 3=40-49 years; group 4= 50 years and over). The ANOVA results in Table 4 indicate that there were significant difference $(p<0.05)$ with regard to ease of use of e-marketing ( $p=0.03 ; F=4.837$ ) for the four age groups. These findings concur with Goldstuck (2009) who affirms that nearly $80 \%$ of South Africa's SMEs perceive ease of use is an important criterion for adopting Internet technology for business activities. The other four factors (External pressure and mission; job performance, resource availability and compatibility) shown no significant differences with the various age categories ( $p>0.05)$.

Table 4: One way analysis of variance (ANOVA) - Age and Drivers of e-marketing adoption

\begin{tabular}{|l|l|c|c|c|c|c|}
\hline \multicolumn{1}{|c|}{ Factor } & \multicolumn{1}{|c|}{ Test } & Sum Of Squares & Df & Mean Square & F & Sig \\
\hline \multirow{4}{*}{ Perceived ease of use } & Between Groups & 19.893 & 3 & 6.631 & 4.837 & $.003^{*}$ \\
\cline { 2 - 7 } & Within Groups & 163.144 & 119 & 1.371 & & \\
\cline { 2 - 7 } & Total & 183.037 & 122 & & & \\
\hline \multirow{4}{*}{ External Pressure and Mission } & Between Groups & .219 & 3 & .073 & .134 & .940 \\
\cline { 2 - 7 } & Within Groups & 64.821 & 119 & .545 & & \\
\cline { 2 - 7 } & Total & 65.040 & 122 & & & \\
\hline \multirow{4}{*}{ Reb performance } & Between Groups & 2.535 & 3 & .845 & 1.357 & .259 \\
\cline { 2 - 7 } & Within Groups & 74.074 & 119 & .622 & & \\
\cline { 2 - 7 } & Total & 76.609 & 122 & & & \\
\hline \multirow{3}{*}{ Compatibility } & Between Groups & 5.891 & 3 & 1.964 & 1.740 & .162 \\
\hline & Within Groups & 134.272 & 119 & 1.128 & & \\
\cline { 2 - 7 } & Total & 140.163 & 122 & & & \\
\hline * Significant at 0.05 level & Between Groups & 6.643 & 3 & 2.214 & 1.680 & .175 \\
\hline & Within Groups & 156.861 & 119 & 1.318 & & \\
\cline { 2 - 7 } & Total & 163.504 & 122 & & & \\
\hline
\end{tabular}

Post-hoc multiple comparisons were undertaken to establish which age groups varied in terms of the ease of use of emarketing. The post-hoc multiple comparisons are reported in Table 5. No differences were found between the age group 1 (under 30 years) and age group 2 (30-39 years) and factor 1 (ease of use) of e-marketing tools. However, those respondents that were between the age group 40-49 years (mean=3.79) and 50 years and over (mean=3.63) differed from their counterparts that were in the age group, under 30 years in terms of the ease of use of e-marketing tools. These findings are consistent with Beheshti and Sangari (2007) who contend that inertia and resistance to Internet technology change is highest among older SME managers and owners. It therefore seems that younger owners/managers of SMEs are more prone to adopt e-marketing tools compared to their older counterparts. This suggests that younger managers value Internet marketing practises and possess a "higher propensity to integrate e- 
marketing within their business practises" (Pearson \& Grandon, 2004:200). These findings are in contradiction with the study of Reimenschneider et al. (2003) that purports that SME adoption decisions are purely process-based (only based on resource control and societal expectations) and individual executive characteristics have no unique effect.

Table 5: Multiple comparisons-Age and ease of use

\begin{tabular}{|c|c|c|c|c|c|}
\hline Dependent Variable & \multicolumn{2}{|c|}{ Age of respondents } & Mean Difference (I-J) & Std. Error & Sig. \\
\hline \multirow{3}{*}{$\begin{array}{l}\text { Factor } \\
\text { Perceived ease } \\
\text { of use }\end{array}$} & \multirow{3}{*}{$\begin{array}{c}1 \text { (under } 30 \text { years) } \\
(\text { Mean }=4.81)\end{array}$} & 2 (30-39 years) (Mean=4.35) & .46230 & .32986 & .501 \\
\hline & & 3 (40-49 years) $($ Mean=3.79) & $1.02778^{*}$ & .32361 & $.010^{*}$ \\
\hline & & 4 (50 years and over) (Mean=3.63) & $1.18611^{*}$ & .40934 & $.023^{*}$ \\
\hline
\end{tabular}

\section{Reliability and Validity of the Study}

The psychometric property of the scale as measured by coefficient alpha $(0.789)$ reflects an acceptable degree of cohesiveness among scale items and provides an indication of the extent to which a set of items are interrelated and internally consistent with each other. According to Nunnally (1978), Cronbach alpha coefficients of less than 0.50 are deemed unacceptable and those between 0.50 and 0.69 are regarded as adequate whereas those over 0.70 are acceptable. The reliability values for all the five dimensions ranged between 0.694 to 0.850 (table 3 ) and these were considered sufficient to conclude that the extracted dimensions are reliable and appropriate to allow for inclusion into the current study.

Content validity refers to items used to measure a construct are conceptually consistent with the definition of a variable (Scheepers, Bloom \& Hough, 2008). To ascertain content validity the instrument was refined during the pretesting stage where a review of the questionnaire was undertaken by five academics after which several changes were made. During this process the researchers were able to ascertain the level of understanding of the concepts proposed in the questionnaire, primarily through feedback received from respondents. During this process superfluous items were removed and wordings of questions edited to suit a South African context. In addition, the questionnaire was pilot-tested with twenty SMEs to ensure that the variables clearly measured the drivers of e-marketing adoption. Discriminant validity was further assessed through the multivariate technique of factor analysis procedure. Those items which loaded on two or more factors (cross-loadings) were deleted. This step of scale purification assists in improving the validity of the research instrument to more satisfactory levels of discriminant validity i.e. all factors loading on only one factor with no cross-loadings (Dhurup \& Mohamane, 2007).

\section{Conclusions and Recommendations for the Study}

The findings of this study provide basic support for a five dimensional structure highlighting the drivers of electronic marketing adoption among SMEs namely; perceived ease of use (PEOU), external pressure and mission, job performance, resource availability and compatibility. These findings concur with other studies that posit that the adoption of e-marketing is multi-dimensional and largely depend on the business sector under investigation (Sparkes \& Thomas, 2001; Stansfield \& Grant, 2003; Kohn \& Husig, 2006).

Marketing managers acknowledge that Internet marketing is effective. A systematic implementation of e-marketing strategies is positively related to the enhanced job performance of SME owner/managers and the overall success of core business processes (Mora-Monge et al., 2010; Morikawo, 2004) and SMEs who fail to implement these systems are set to jeopardize the potential returns of their businesses.

Numerous companies have adopted a 'wait-and-see' attitude toward the adoption of e-marketing strategies in the SME industry in South Africa (Cloete, 2006). As soon as successful champions emerge (innovators), many companies will be able to seriously consider participation. Increasing numbers of SMEs in South Africa are adopting Internet marketing technology as a means of communication and distribution under competitive pressure from global suppliers and customers. This underlying determinant is further compounded by the perceived usability of e-marketing tools as defined by design, flexibility, understandability and ease of use. This is because once potential adopters perceive technology to be complex then this reduces the chances of it being applied within their business processes. There remains immense need to encourage increased SME participation in online marketing platforms, through media hype and advertising campaigns. Such a media drive can go a long way in strengthening the SMEs' ability to commit financial 
and human resources towards the development of e-marketing and enhancing the e-readiness of SMEs.

SMEs are encouraged to install some social software platforms in order to stimulate digital communities and collaborations with their trading partners (customers, suppliers, governments). This will aid in creating knowledge sharing environments and network developments as these go a long way in facilitating social networking, globalisation and ultimately, firm internationalisation. The ordeals of distance and size are bridges and the smaller firm is better able to maintain competitive advantage.

Government grants and subsidies may be developed at national level in order to support the development of skills within the ICT sector in line with the South African Workplace Skills Plan. Furthermore, collaborations with foreign based organisations may go a long way in accelerating the exposure to the international environment as well as technology transfer among South African SMEs. Additionally, industrial co-ordination may be forged amongst SMEs, banks and the government in order to assist small firms with loans and other forms of long-term financing. These measures will help to broaden the participation of both firms and individuals in Information Technology (IT) usage and this will undoubtedly reflect positively on the GDP of the country. Moreover, firms will be better able to overcome the barriers of size thus levelling the playing field between SMEs and their larger counterparts.

In order to enhance the Internet technology readiness of South African SMEs, it is necessary that formal education and awareness tools be introduced starting from national level in order to avert scant adoption of e-marketing. Adoption can rarely take off unless companies and individuals are educated about the opportunities offered by Internet related technologies (Stansfield \& Grant, 2003).

\section{Limitations and Implications for Future Research}

This study adds to the body of knowledge and the growing literature on e-marketing adoption and its drivers. Focus is on SMEs operating within South Africa, a newly industrialised country hence, there is a possibility that measures of adoption in developing and newly industrialised nations may vary from those businesses operating in the first world countries. The limited sample size of 123 respondents used in this study further indicates that caution is needed in the interpretation of these findings as these results cannot be accepted as completely germane to other provinces in South Africa. The study was conducted in one region only; the results obtained in other regions within the country may differ.

A combination of quantitative and qualitative research methods is recommended for future research which may expand to include large enterprises and the effects of national culture and lifestyle as e-marketing drivers. Additionally, a review of past established models such as TAM (Davies et al., 1989) is warranted in future studies. Cross-country comparative studies may be undertaken with a view to identify the differences in e-marketing adoption within different organisational settings. In light of such studies, an appropriate adoption instrument specifically suited for South African SMEs may be posited. This may be established by both academic and industry experts with a view to establishing the relevant skills and techniques that may be needed to increase the efficiency of Internet marketing tools.

\section{References}

Abrahams, L. \& Goldstuck, A. (2010). ICT, the network knowledge economy and development. LINK Public Policy No. 11, July. [Online] available:http//link.wits.ac.za/papers/Abrahams-Goldstuck-2010-eDevelopment-SA.pdf (14 November 2012).

Awa, H. O., Nwibere, B. M. \& Inyang, B. J. (2010). The uptake of electronic commerce by SMEs: a Meta theoretical framework expanding the determining constructs of TAM and TOE frameworks. Journal of Global and Business Technology, 6(1), 1-27.

Bakos, Y. \& Treacy, M. (1986). Information technology and corporate strategy: A research Perspective. Management Information Systems Quarterly, 14(4), 259-267.

Barry, H. \& Milner, B. (2002). SMEs and E-Commerce; a departure from the traditional prioritisation of training? Journal of European Industrial Training, 26(7), 316-326.

Beheshti, H. M. \& Sangari, E. S. (2007). The benefits of e-business adoption an empirical study of Swedish SMEs. Service Business Journal, 1(3), 233-245.

Bruque, S. \& Moyano, J. (2007). Organisational determinants of information technology adoption and implementation in SMEs: the case of family and cooperative firms. Technovation, 27(1), 241-253.

Burgess, S. M. \& Bothma, C. H. (2007). International Marketing. Cape Town: Oxford University Press.

Chaffey, D. \& Smith, P. R. (2005). E-marketing excellence; the heart of e-business. (2nd ed.). Oxford: Heinemann.

Chan, C. \& Swatman, P. M. C. (2000). From EDI to E-Commerce: the BHP experience. International Research and Electronic Networking Applications and Policy, 10(1), 72- 82.

Chaston, I. (2000). Entrepreneurial Marketing; competing by challenging conventions. London: Macmillan Business Press.

Chaston, I. \& Mangles, T. (2003). Relationship marketing in online business to business markets: a pilot investigation of small UK 
manufacturing firms. European Journal of Marketing, 37(5/6), 753-773.

Chau, P. (1996). An Empirical Assessment of a Modified Technology Acceptance Model. Journal of Management Information Systems, 13(2), 185-204.

Clarke, C. (2000). Coming attraction. Wired Review, 17(12), 12-16.

Cloete, E. (2006). Aspects of E-Marketplaces in South Africa. Paper presented at the fourth International Science and Technology Conference held at the Vaal University of Technology on 28 to 30 November 2006.Vanderbijlpark: South Africa, 1-27.

Cronje, G. J., Du Toit, J. \& Motlatla, M. (2004). Introduction to Business Management. (6 $6^{\text {th }}$ ed.). Cape Town: Oxford Business Press.

Davies, F. D., Bagozzi, R. P. \& Warshaw, P. R. (1989). User acceptance of computer technology: a comparison of two theoretical models. Management Science Journal, 35(8), 982-1003.

Dhurup, M. \& Mahomane, P. B. P. L. (2007). Assessing internal marketplace relationships: measuring internal service quality within a petrochemical company. Southern Africa Business Review, 11(2), 56-78.

Dlodlo, J. B., Nleya, B. M, \& Adigun, M. O. (2006). Providing wireless QOS by integration of Intelligent Software Agents. Paper presented at the fourth International Science and Technology Conference held at the Vaal University of Technology on 28 to 30 November 2006, Vanderbijlpark: South Africa, 1-17.

Elliot, R. \& Boshoff, C. (2007). The influence of the owner-manager of small tourism businesses on the success of Internet Marketing. South African Small Business Journal, 38(3), 15-27.

Esteves, J. (2009). A benefits realization road-map framework for ERP usage in small and medium sized enterprises. Journal of Enterprise and Information Management, 22(1/2), 25-35.

Falkena, H. (2000). SMEs access to Finance in South Africa; a supply side regulatory review. Report by the task group of the policy board to financial services and regulations: Pretoria, South Africa: Kluwer Publishers.

Fathian, M., Akhavan, P. \& Hoorali, M. (2008). E-Readiness Assessment of Non-Profit ICT SMEs in a Developing Country: The Case of Iran. Technovation, (3), 578-597.

Federici, T. (2009). Factors influencing ERP outcomes in SMEs: A post-introduction assessment. Journal of Enterprise and Information Management, 22(1/2), 81-98.

Fillis, I., Johannson, U. \& Wagner, B. (2004). Factors impacting on e-business adoption and development in the smaller firm. International Journal of Entrepreneurship and Behavioural Research, 10(3), 178-191.

Gay, R., Charlesworth, A. \& Esen, R. (2007). Online Marketing: a customer-led approach. New York: Oxford University Press.

Gibson, T \& van der Vaart, H. J. (2008). Defining SMEs: a Less Imperfect Way of Defining Small and Medium Enterprises in Developing Countries. [online] Available :http://www.brookings.edu/ /media/research/files/papers/2008/9/development\%20gibson/09 _development_gibson.pdf (20 January 2013).

Gilmore, A., Gallagher, D. \& Henry, S. (2007). E-Marketing and SMEs: operational lessons for the future. European Business Review, 19(3), 234-247.

Ghobakhloo, M., Arias-aranda, D. \& Benitez-amado, J. (2011). Adoption of e-commerce applications in SMEs. Journal of Industrial Management Data Systems, 111(8), 1238-1269.

Goldstuck, A. (2009). Make it easy: SMEs want mobility and simplicity, iWeek, 206, pp.11.

Hair, J. F., Anderson, R. E., Tatham, R. L. \& Black, W. C. (1992). Multivariate data analysis with readings. (3rd ed.) New York: McMillan Publishing Company.

Harris, L. \& Dennis, C. (2002). Marketing the e-Business. London: Routledge Publishers.

Harrison, T. \& Waite, K. (2006). A time based assessment of the influences, uses, and benefits of Intermediary website adoption. Journal of Information Management, 43(1), 1002-1013.

Hollenstein, H. (2004). Determinants of the adoption of Information and Communication Technologies (ICT); an empirical analysis based on firm-level data for the Swiss business sector. Structural Change and Economic Dynamics, 15(3), 315-342.

Jackson, M. L. P. (2004). Entrepreneurial support in South Africa: a case study of a small enterprise support centre in Johannesburg. Thesis submitted for the degree Philosophie Doctor in Business Management. Birmingham: University of Birmingham.

Jutla, D., Bodorick, P. \& Dhaliwal, J. (2002). Supporting the E-Readiness of small and medium sized enterprises: approaches and metrics. International Research and Electronic Networking and Applications Policy, 12(2), 139-164.

Kendall, J. D., Tung, L. L., Chua, K. H., Dennis, N. G, C. H. \& Tan, S. M. (2001). Receptivity of Singapore's SMEs to electronic commerce adoption. Journal of Strategic Information Systems, 10(1), 223-242.

Khan, S. (2007). Adoption issues of Internet banking in Pakistani firms. Dissertation submitted for the degree Master of Science in Information Technology. Lulei: Lulei University of Technology.

Kohn, S. \& Husig, S. (2006). Potential benefits, current supply, utilization and barriers to adoption: an exploratory study of German SMEs. Technovation, 26(1), 988-998.

Kyobe, M. (2011). Special issue on information and communication technology in South Africa. Journal of Systems and Information Technology, 13(3), 1-2.

Lee, O. K. M. \& Cheung, C. M. K. (2004). Internet retailing adoption by small and medium sized enterprises (SMEs): a multiple case study. Information Systems Frontier, 6(4), 385- 397.

Levy, M. \& Powell, P. (2002). SME Internet adoption: towards a transporter model. Paper read at the $15^{\text {th }}$ BLED Electronic Commerce conference on eReality: constructing the eEconomy held in Slovenia on 17 to 19 June. Slovenia.

Lim, W. M. (2010). Factor Analysis of Variables affecting e-Marketing Adoption by UK Independent hotels. Information Communications and Technology Journal, 2(1), 39-50. 
Maguire, S., Koh, S. C. L. \& Magrys, A. (2007). The adoption of E-Business and knowledge management in SMEs. Benchmarking: An International Journal, 14(1), 37-58.

Malhotra, N. K. (2010). Marketing research: An applied orientation. (6 $6^{\text {th }}$ ed.). New Jersey: Pearson Prentice-Hall.

Martin, L. M. (2005). Internet adoption and use in small firms: internal processes, organisational culture and the roles of the ownermanager and key staff. New Technology, Work and Employment, 20(3), 190-204.

Martin, L. M. \& Matlay, H. (2001). Blanket approaches to promoting ICT in small firms: Some lessons from DTI ladder adoption model in UK. Internet Research: Electronic Networking Applications and Policy, 11(5), 399-410.

Matlay, H. \& Addis, M. (2003). Adoption of e-commerce and ICT in small businesses: an HEI based consultancy perspective. An HEI based consultancy perspective. Journal of Small Business and Enterprise Development, 10(3), 321-335.

Mehrtens, J., Cragg, P. B. \& Miller, A. M. (2001). A model of Internet adoption by SMEs. Information Management Journal, 39(1), 165176.

Miniwatts Marketing Group (2011). Internet usage statistics: world internet user and population stats, Internet, World Stats. [Online] Available: www.internetworldstats.com/stats.htm (24 October 2013).

Modimogale, L. \& Kroeze, J. H. (2011). The role of ICT within Small and Medium Enterprises in Gauteng. Communications of the IBIMA Journal, 2011(1), 1-13.

Moodley, S. (2002). Global market access in the Internet era: South Africa's wood furniture industry. International Research and Electronic Networking and Applications Policy, 12(1), 31-42.

Mora-Monge, C. A., Azadegan, A. \& Gonzalez, M. E. (2010). Assessing the impact of web-based electronic commerce use on the organizational benefits of a firm: An empirical study. Benchmarking: An International Journal, 17(6), 773-790.

Morikawo, M. (2004). Information technology and the performance of Japanese SMEs. Small Business and Economics Journal, 23(1), 171-177.

Mutula, S. (2002). Current developments in the Internet industry in Botswana. Electronic Library Journal, 20(6), 504-511.

Mutula, S. \& van Brakel, P. (2006). E-readiness of SMEs in the ICT Sector in Botswana with Respect to Information Access. Electronic Library Journal, 24(3), 402-17.

Nunnally, J. C. (1978). Psychometric Theory. (2nd ed.). New York: McGraw Hill.

Opia, O. (2008). An Exploratory study of the Moderating effects of Trust on E-commerce Adoption Behaviour of Nigerian small Enterprises. African Journal of Entrepreneurship, 1(1), 43-51.

Parker, C. \& Castleman, T. (2009). Small firm E-business Adoption: A critical analysis of theory. Journal of Entrepreneurship and Information Management, 22(1/2), 167-82.

Pearson, M. J. \& Grandon, E. E. (2004). Electronic commerce adoption: empirical study of small and medium sized US businesses. Journal of Information Management, 42(1), 197-216.

Poon, S. \& Swatman, P. M. C. (1997). Small business use of the Internet. International Marketing Review, 14(5), 385-402.

Poon, S. \& Swatman, P. M. C. (1999). An exploratory study of small business Internet commerce issues. Journal of Information Management, 35(1), 9-18.

Porter, M. (2001). Strategy and the Internet. Harvard Business Review, 79(3), 63-78.

Quayle, M. (2002). E-Commerce: the challenge of UK SMEs in the $21^{\text {st }}$ century. International Journal of Operations and Production Management, 22(10), 1148-1161.

Qingfei, M. I. N., Shaobo, J. I. \& Gang, Q. U. (2008). Mobile Commerce User Acceptance Study in China: A Revised UTAUT Model. Tsinghua Science and Technology Journal, 13(3), 257-264.

Ramsey, E. \& McCole, P. (2005). E-Business in professional SMEs: the case of New Zealand. Journal of Small Business and Enterprise Development, 12(4), 528-544.

Rashid, M. A. \& Al Qirim, N. A. (2001). E-Commerce technology adoption framework by New Zealand small to medium sized employees. Research Letters in the Information Management Systems Journal, 3(2), 63-70.

Reimenschneider C.K., Harrison, D.A. \& Mykytyn, P.P. (2003). Understanding it adoption in small business: integrating current theories, Information \& management journal, 40(1), 269-285.

Republic of South Africa (1996). National Small Business Act No. 102 of 1996. Cape Town: Government Gazette 1907, 27 November.

Republic of South Africa (2005). Department of Trade and Industry. National Strategy for the Development and Promotion of Small Business in South Africa. Cape Town: Government Printer. (Notice 213 of 2005, 16317).

Republic of South Africa (2009). Parliamentary Monitoring Group report; productivity SA, Unemployment Insurance Fund and Compensation Fund: Strategic Plans 2009-10, August 26.

Rogers, E. M. (1995). Diffusion of innovations. (4th ed.). New York: Free Press Publishers.

Sadowski, B. M., Maitland, C. \& Dongen, J. V. (2001). Strategic use of the Internet by small and medium-sized companies: an exploratory study. Journal of Information and Economics Policy, 14(1), 75-93.

Saffu, K., Walker, J. H. \& Hinson, R. (2008). Strategic value and electronic commerce adoption among small and medium-sized enterprises in a transitional economy. Journal of Business and Industrial Marketing, 23(6), 395-404.

Scheepers, M. J., Bloom, J. Z. \& Hough, J. (2008). The development of an instrument to assess the enacted environment for corporate entrepreneurship in South Africa. Management Dynamics, 17(4), 2-17.

Shiau, W., Hsu, P. \& Wang, J. (2009). Development of Measures to Assess the ERP Adoption of Small and Medium Enterprises. Journal of Enterprise and Information Management, 22(1/2), 99-118.

Singh, M. A. (2002). The Internet-Strategies for optimal utilization in South Africa. South African Journal of Information Management, 
$4(1), 1-11$.

Soontiens, W. (2002). Managing International Trade: an analysis of South African SMEs and regional trade. Journal of Management Decisions, 40(7), 710-719.

Sparkes, A. \& Thomas, B. (2001). The use of the Internet as a critical success factor for the marketing of Welsh-agri food SMEs in the twenty first century. British Food Journal, 103(5), 331-347.

Stansfield, M. \& Grant, K. (2003). An investigation into issues influencing the use of the Internet and electronic commerce among smallmedium sized enterprises. Journal of Electronic Commerce Research, 4(1), 15-33.

Steyn, A.S. \& Leonard, A. C. (2012). Guidance for SMEs with the adoption of technology: A conceptual gramework. The Southern African Journal of Entrepreneurship and Small Business Management, 5(1), 24-33.

Tassiopoulos, D. (2010). An investigation into the co-producers of preferred strategic behaviour in Small, Micro and Medium tourism enterprises in South Africa. Thesis submitted for the degree Philosophie Doctor in Business Management and Administration. Cape Town: Stellenbosch University.

Teo, T. S. H. \& Tan, M. (1998). An empirical study of adopters and non-adopters of the Internet in Singapore. Journal of Information Management, 34(1), 339-345.

Triandis, H. (2004). The many dimensions of culture. Academy of Management Executives, 18(1), 88-93.

United Nations (2004). E-commerce and Development Report, United Nations Conference on Trade and Development, UNCTAD/SDTE/ECB/2004/1: New York and Geneva.

Uzoka, F. M. E., Shemi, A. P. \& Seleka, G. G. (2007). Behavioural influences of E-Commerce adoption in a developing country context. Electronic Journal of Information Systems in Development Countries, 31(4), 1-15.

Venkatesh, V. (2000). Determinants of Perceived Ease of Use: Integrating Control, Intrinsic Motivation and Emotion into the Technology Acceptance Model. Information Systems Research, 11(4), 342-365.

Vuuren, van J. J. \& Groenewald, D. (2007). A critical analysis of the influence of start-up factors in small businesses and entrepreneurial ventures in South Africa. Acta Commercii, 4(1), 269-280.

Whiteley, D. (2000). E-commerce: strategy, technologies and applications. London: McGraw Hill.

Zaayman, P. (2003). Functional Requirements of eCRM solutions for the South African SME sector. Dissertation submitted for the degree Master of Philosophy, Johannesburg, Rand Afrikaans University.

Zhao, F. (2005). Entrepreneurship and innovations in e-business: an integrative perspective. International Journal of Entrepreneuship and Innovation, 6(1), 53-60. 